\title{
智能控制技术发展的思考
}

\section{包为民 ${ }^{1 *}$, 衩振强 ${ }^{2}$, 张玉 $^{3}$}

1. 中国航天科技集团有限公司科技委, 北京 100048

2. 中国运载火箭技术研究院, 北京 100191

3. 北京航天自动控制研究所, 北京 100854

* 通信作者. E-mail: baoweimin@cashq.ac.cn

收稿日期: 2019-11-19; 接受日期: 2019-12-31；网络出版日期: 2020-08-04

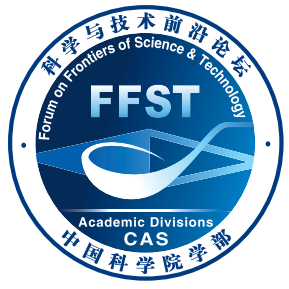

摘要人工智能技术蓬勃发展, 理论与技术上都有显著突破, 在诸多领域得到了广泛应用; 人工智能 的相关理论与技术成果有可能在控制领域得到最大的集成，即智能控制将是人工智能及相关前沿技术 的综合体现. 本文从控制科学与技术的发展历程切入, 分析得出智能控制将是人工智能与工业界融合 发展的抓手, 进而对智能控制的发展需求、控制技术的智能化途径和智能控制的发展阶段以及各阶段 性特征展开讨论, 最后阐述了推动智能控制技术发展的重点方向.

关键词人工智能, 控制学科发展, 智能控制发展需求, 控制技术智能化

\section{1 引言}

人工智能技术作为当今最具颠覆性和变革性的技术, 其发展战略已上升到国家层面, 主要国家进 入了全面推进人工智能发展的全新战略时代. 世界主要发达国家纷纷出台规划和政策, 力图在新一轮 国际科技竞争中掌握主导权. 2019 年, 美国接连发力, 先后发布了《理解中国 AI 战略》《国防部人工 智能战略摘要》, “保持美国人工智能领导力” 的行政命令, 以及国家人工智能倡议法案等, 强势推动 人工智能的快速发展与应用.

机器学习算法不断突破、计算能力迅速提高, 伴随 $5 \mathrm{G}$ 时代、大数据和物联网的到来, 无人系统 完成自主更复杂的任务成为可能, 人工智能发展步入了新阶段, 呈现出深度学习、跨界融合、人机协 同、群智开放、自主操控等新特性 ${ }^{[1]}$, 并渗透到社会生产生活的各个方面, 成为引领未来的战略性 技术.

控制论是一门研究机器、生命、社会中控制和通讯的一般规律的科学, 是研究动态系统在变化的 环境条件下如何保持平衡状态或稳定状态的科学 [2]. 综合分析, 我们认为: 人工智能的理论与技术成 果最有可能在控制领域得到最大的集成, 智能控制将是人工智能及相关前沿技术的综合体现, 发展智 能控制技术会具有极强的带动性.

为了系统地理解并更好地推动智能控制技术发展, 本文将从控制科学与技术的发展、智能控制发 展需求、控制技术的智能化、智能控制发展之路等多个角度展开探讨. 


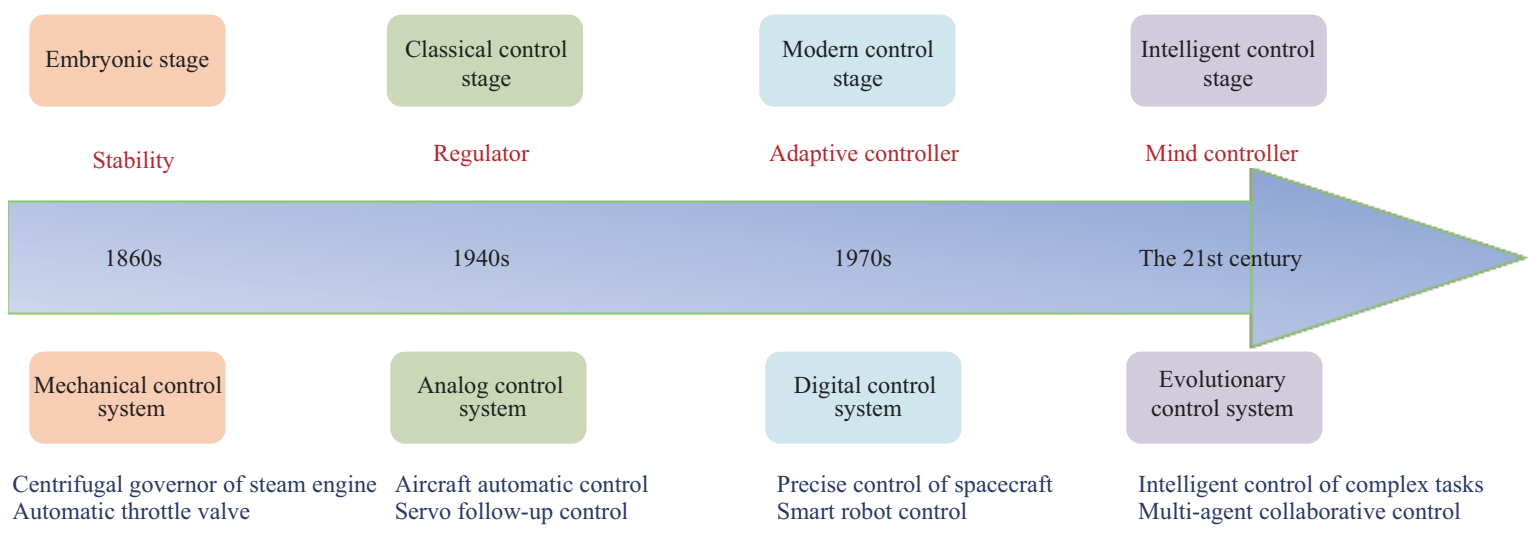

图 1 (网络版彩图) 控制科学的发展历程

Figure 1 (Color online) Development of control science and technology

\section{2 控制科学与技术的发展}

控制科学的发展历程 (图 1) 可大致分为: 萌芽时期、古典控制时期、现代控制时期以及智能控制 时期. 萌芽时期: 机械化在大工业中的广泛应用引发了对自动控制的研究. 1868 年, Maxwell ${ }^{[3]}$ 深入研 究了蒸汽机调速系统中出现的剧烈振荡的不稳定问题, 并给出增加系统阻尼使之稳定的解决办法, 由 此产生了稳定性等基本概念. 在自动控制和通讯技术的推动下, 控制理论在 20 世纪上半叶取得了一 系列重要成果, Wiener 等 [2] 创立了控制论这门独立学科, 并提出了 “反馈” 这个最核心的概念; 出现 了伺服随动控制、飞机自动控制、工业化生产的现场控制等模拟式控制系统, 并得到良好应用. 自 20 世纪 50 年代中期起, 迅速兴起的空间技术的发展迫切要求建立新的控制理论 ${ }^{[4]}$, 诸如航天器精准控 制等以状态空间方法为基础、用以分析和设计控制系统的现代控制理论和数字式控制系统应运而生. 随着应用背景的扩大, 我们需要建立分布式多参数系统、非线性系统、随机系统等更为复杂系统的控 制理论与方法来解决日益增长的任务需求, 而智能控制的发展与应用将是行之有效的解决途径.

“思维控制器” 是人工智能技术和现代控制技术紧耦合的产物, 可以模拟人和高级生物头脑中较 高级的活动, 可以处理复杂、陌生环境的控制任务, 即运用联想、演绎、规则推理等手段, 开展非结构 化建模、模型预测修校、陌生环境知识迁移、不完全信息的决策判断、人工情感控制等的一类控制器. “进化式控制系统” 是思维控制器的工程实现, 算法设计层面上, 传统参数调节将向新的算法演绎方式 拓展; 硬件实现层面上, 已有架构模式局部适应将向新的架构演化拓展. 也就是, 控制系统的架构、软 件、硬件等, 可以根据输入 (包括任务目标变更等)、约束 (包括环境、边界、终端等)、对象模型的演绎 等各方面的需求, 可以演化和自组织以实现满意的控制效果的系统. 根据模型对象、环境实际情况, 开 展 “硬件自演化、软件自配置、算法自生成” 以实现 “个体自修复、群体自组织”, 最终完成满意控制 品质实现.

以史为鉴, 可知兴替. 纵观控制科学与技术的发展历程, 不难得出: 控制理论的重大进展均取决于 社会生产力的需要和人类已有知识的准备, 工程系统的任何重大进展也均取决于控制理论水平和器件 与工业制造水平.

智能控制是控制理论的第 3 个里程碑, 也是人工智能与工业界融合发展的抓手. 1965 年, 美籍华 人科学家傅京孙首先提出把人工智能的启发式推理规则用于学习控制系统. 十多年后, 建立实用智能 控制系统的技术逐渐成熟. 1971 年, 傅京孙提出把人工智能与自动控制结合起来的思想. 1977 年, 美 
国人萨里迪斯 (G. N. Saridis) 提出把人工智能、控制论和运筹学结合起来的思想. 关于智能控制的定 义和内涵, 多年来国内专家学者 ${ }^{[5 ~ 9]}$ 也纷纷给出了诠释和研究, 本文从航天工程和无人系统研发的视 角给出理解和认识: 所谓智能控制就是根据无人系统的要求, 由机器自主实现其目标的过程, 或由人 在远端与智能机器融合的方式驱动机器实现其目标的控制, 这类无人系统具有学习、抽象、推理、决 策、衍化等功能, 并能根据环境 (包括被控对象或被控过程) 信息的变化作出适应性反应, 从而实现由 人来完成的任务. 智能控制的发展阶段与特征可概括为: (1) 提升应对变化能力, 控制系统关键环节的 智能化; (2) 具备学习能力, 能够学习先进、跟随模仿 (可学习、可训练); (3) 具有泛化能力, 能够举一 反三、超越常识认知; (4) 具备演化、进化能力, 能够发现问题并解决问题.

\section{3 智能控制的发展需求}

控制科学与技术在能源、交通、航天等体现国家重大战略需求的诸多领域均有重要的应用. 例如, 在能源领域, 解决大型电力系统尤其是超大规模输配电、发展受控核聚变能等; 在交通领域, 解决交通 系统的规划、研判、调度等; 在我国航天事业的发展进程中, 更是实施两弹一星、载人航天、探月工程 等国家科技工业重大项目不可缺少的设计理论与方法. 而智能控制的应用, 将为各领域发展注入新的 活力, 满足系统持续发展的需求, 成为变革性发展的助推器.

中国的发展已经进入新时代, 在建设航天强国的征程中, 更要聚焦进出空间、利用空间、开发空间 和探索空间 4 大能力, 发展新型航天系统需要有低成本高可靠进出空间的航天运输系统、高效高性能 空间系统 (星座、空间站等) 以及太空制造、深空探测和开发系统. 因此, 进一步提升航天控制的智能 化水平, 增强对不确定性和突发情况的适应能力, 保证高可靠安全运行, 是航天工程发展和航天强国 建设的迫切需求.

我国的航天工业经过六十余年的发展，航天技术日益凸显军民融合的特征，航天与智能相结合 将呈现新的应用前景：(1) 空间基础设施将更高效、更精准; (2) 低成本航天运输将更可靠、更快捷; (3) 深空探测任务将更自主、更深远; (4) 导弹武器装备将更实战、更协同.

不同于其他工业领域, 航天系统具有飞行环境不确定、故障模式不确定、外部干扰不确定、自身 模型不确定、飞行任务不确定等特有属性. 虽然经过 60 多年的发展, 航天控制工程实践研究积累了一 批方法, 诸如增益时变控制、自适应控制、协调解耦控制等, 并在多个航天工程中得到了实践, 有效应 对了航天工程中的不确定性. 但这些方法的系统性还不够, 应对多因素不确定性的能力不足, 未能全 面、整体地解决问题, 而智能控制则可能给出系统性、综合性的解决方案. 由此, 智能控制技术将成为 实现智能航天的必然选择.

总体而言, 智能控制的发展需求主要体现在以下 3 个方面:

(1) 大型工程的实施需要控制方法更具创造性. 例如, 完备的空间互联网星座部署、未来深空探测 计划、智慧交通与自动驾驶等.

(2) 复杂系统运行需要更强的感知、适应、规划与学习. 包括: 多信息源的获取、传播、融合、处 理; 复杂环境条件下的主动适应与利用, 复杂执行机构的协调控制, 根据控制效果智能调整控制策略; 给定能力与约束、给定任务目标下的自主任务规划; 基于环境与资源的硬件进化与系统优化; 典型故 障条件下的智能容错与智能重构; 基于任务与知识的算法进化演示等.

(3) 智能特征的实现需要控制与信息的更深度融合. 控制的基础是用数学工具处理信息, 信息的传 递都是为了更好地实现控制意图, 而任何控制又都有赖于对控制目标的信息反馈来实现. 人工智能使 控制与信息的获取、处理、传输等进行有机结合, 并有助于实现对数据的深度挖掘, 加深对系统对象的 
认知理解.

“人工智能” 已经连续三年被写入政府工作报告, 并在 2019 年提出要 “拓展 “智能 +', 深化人工智 能研发应用”. 在智能化背景下, 制造业、旅游业、服务业等一批传统产业, 再度焕发新活力, 有力促进 经济社会的发展; 地月空间资源开发、能源利用、在轨制造等新产业将成为国际热点, 我们应当抓住机 遇, 助力新兴产业, 培育新动能, 迎接太空经济的到来.

\section{4 控制技术的智能化}

智能控制的发展不是一蹴而就, 也要遵循事物发展的规律, 即从 “+ 智能” 到 “智能 +” 的发展, 起好步、走稳 “十 智能” 的发展阶段, 是智能控制技术发展的关键. 目前, 控制技术的智能化应聚焦 5 个关键环节, 即智能感知与识别、智能控制律与机构、智能计算与规划决策、智能协同与博弯、智能 网络与安全. 我们要从基础理论与关键技术两个维度研究发力, 并使二者相互促进、相互成就.

(1) 智能感知与识别. 即对被控对象本体、所处的环境, 以及环境中存在的其他对象, 具有一定程 度的了解; 对原始的测量信息进行更深层的处理与加工, 例如提取特征、融合信息、层层抽象, 具有一 定程度的理解能力.

基础理论包括: 认知探测基础理论与方法, 新型仿生感知识别理论与方法, 感知、记忆、推理一体 化的全自主探测方法, 类人识别, 高级机器学习机理, 人类快速学习和知识迁移的基础理论与方法, 先 验知识欠缺条件下场景理解和语义表示方法等.

关键技术包括: 环境信息与本体状态的智能感知与认知技术、基于大数据与知识的场景快速推理 技术、宽频谱可重构综合感知与认知无线电技术、基于分布式传感器的全景式综合感知技术、大范围 复杂动态场景表征与认知技术、复杂态势深度认知与评估技术、故障智能诊断与快速定位技术等.

(2) 智能控制律与机构. 即在控制律中引入智能化的算法, 显著提升自适应能力; 递进开展思维控 制器和进化式控制系统设计所需的理论与方法研究, 使控制器具备更显著的自学习、自组织等特点; 将新材料、新工艺应用于执行机构, 使得更高的控制品质成为可能.

基础理论包括: 思维控制器相关理论与方法、自主学习与行为控制理论、超大型柔性机构高精度 高稳定度指向控制理论、多任务的迁移学习方法和增量学习方法、数字仿真与物理实验交互修正的平 行学习方法、协同控制与优化决策理论、基于多目标优化的自主重构策略等.

关键技术包括: 进化式系统设计技术、基于数据挖掘与数据驱动的制导控制技术、飞行状态辨识 与主动适应控制技术、自主智能体的灵巧精准操作学习控制技术、极高精度测量与指向稳定度控制技 术、深空人机结合大时延遥操作控制技术、多层次人在回路的智能控制技术、智能材料按需主动可控 变形技术等.

(3) 智能计算与规划决策. 即以高级机器学习为代表的智能化信息处理算法, 算力更强、能耗更低 的计算体制与计算装置; 更高效、更优化地求解复杂的大规模规划问题与决策问题.

基础理论包括: 具有推理、理解、联想特征的智能认知理论、数据驱动和知识指导相结合的人工 智能理论、适应小数据与增量数据的机器学习理论、复杂数据和任务的人机混合增强智能学习方法、 自主无人系统的协同感知与交互理论、可解释的人工智能理论等.

关键技术包括: 低能耗轻量化的智能计算技术、高速并行计算技术、分时分区分布计算技术、类 脑计算制导与控制技术、跨媒体分析推理技术与应用、大规模数据挖掘与知识自动提取技术等.

(4) 智能协同与博亦. 即多个智能体之间的运动协同、信息协同与功能协同, 从而增强整体效能; 基于群体智能的涌现与演化机理, 在非合作、强对抗、高动态、信息不完整等条件下, 实现智能群体的 
体系化协同与博弯.

基础理论包括: 动态、不确定、不完全信息下智能博弯决策理论, 开放动态复杂环境下自主无人 系统群智涌现与演化理论, 群体决策与机制设计理论, 个体之间的知识共享和并行学习方法等.

关键技术包括: 基于增强学习和推演的规划与决策技术、复杂不确定环境下的智能实时推理和对 抗技术、任务在线优化分配与博亦效果自主评估技术、体系条件下多智能体联合快速任务规划技术、 面向群体行为的群智激发汇聚技术等.

(5) 智能网络与安全. 即多节点、跨地域、高速率、有弹性的信息网络, 抗干扰、抗攻击的高可靠 网络安全.

基础理论包括: 分布式协同通信策略、太赫兹通信理论、量子通信理论、精准通信与抗干扰通信、 信息网络系统的智能主动防御等.

关键技术包括: 智能频谱管理与资源分配技术、高安全高可靠强实时智能通信技术、云协同网络 及信息应用技术、空间激光通信与激光测距、激光成像一体化技术、智能体间协同信息网络与智能通 信技术、网络抗毁安全路由关键技术、软件漏洞自动挖掘与分析利用技术等.

\section{5 结论}

未来的智能控制发展之路将是智能控制与新的复杂系统的结合, 与相关交叉学科的融合, 需要结 合智能控制发展的阶段性特征展开持续探索. 我们将深入推进智能技术研究成果的航天工程应用, 同 时也将着力开展基础性研究, 在人工智能技术的可解释性、可控性、可信性等方面探索研究, 航天智能 控制技术将不断融合新方法, 解决新问题, 拓展新应用, 攀登新高度!

\section{参考文献}

1 中华人民共和国国务院。新一代人工智能发展规划。2017. http://www.gov.cn/zhengce/content/2017-07/20/ content5211996.htm

2 Wiener N. Cybernetics or Control and Communication in the Animal and the Machine. Cambridge: The MIT Press, 1948

3 Maxwell J C. On governors. Proc R Soc Lond A, 1868, 16: 270-283

4 Zhang X. Thoughts on the development of control subjects. TCCT Commun, 2014, 7 [张旭. 关于控制学科发展的若 干思考. TCCT 通讯, 2014, 7]

5 Huang L, Yang Y, Li Z K. Thoughts on intelligent control. Sci Sin Inform, 2018, 48: 1112-1120 [黄琳, 杨荣, 李忠奎. 关于智能控制的几个问题. 中国科学: 信息科学, 2018, 48: 1112-1120]

6 Wu X-F, Cai Z-X. The development and future of automatic control. Autom Petro-Chemical Industry, 1999, 5: 6-7 [吴晓帆, 蔡自兴. 自动控制的发展与未来. 石油化工自动化, 1999, 5: 6-7]

7 Wu H X, Xie Y C. Intelligent control of golden section based on feature model description. In: Proceedings of China Intelligent Automation Academic Conference, 1996. 409-419 [吴宏金金,解永春. 基于特征模型描述的黄金分割智能控 制. 见: 中国智能自动化学术会议论文集, 1996. 409-419]

8 Dai R W. Overview of artificial intelligence. China Comput Users, 1989, 8: 14-17 [戴汝为. 人工智能概述. 中国计算 机用户, 1989, 8: 14-17]

9 Zhang B. Artificial intelligence and automatic control. In: Proceedings of the 3rd National Symposium on Robotics, 1990. 22-26 [张钹. 人工智能与自动控制. 见: 全国青年第三届机器人学研讨会论文集, 1990. 22-26] 


\title{
Thoughts on the development of intelligent control technology
}

\author{
Weimin $\mathrm{BAO}^{1 *}$, Zhenqiang $\mathrm{QI}^{2} \& \mathrm{Yu} \mathrm{ZHANG}^{3}$ \\ 1. Science and Technology Commission of China Aerospace Science and Technology Corporation, Beijing 100048, \\ China; \\ 2. China Academy of Launch Vehicle Technology, Beijing 100191, China; \\ 3. Beijing Aerospace Automatic Control Institute, Beijing 100854, China \\ * Corresponding author. E-mail: baoweimin@cashq.ac.cn
}

\begin{abstract}
With the rapid development of the artificial intelligence technology, significant breakthroughs in its theory and applications have been widely used in many fields. The related theories and technical achievements of artificial intelligence are likely to be integrated to the maximum extent in the field of control; that is, intelligent control will become the comprehensive embodiment of the artificial technology. This study starts with an overview of the development of the control science and technology, and concludes that intelligent control will become a starting point for the integration of artificial intelligence and industry. Then, the study discusses the development requirements of intelligent control, ways of control technology intellectualization, development stages of intelligent control, and characteristics of each stage. Finally, the key direction of promoting the development of the intelligent control technology is described.
\end{abstract}

Keywords artificial intelligence, control discipline development, intelligent control development requirement, intelligence of control technology

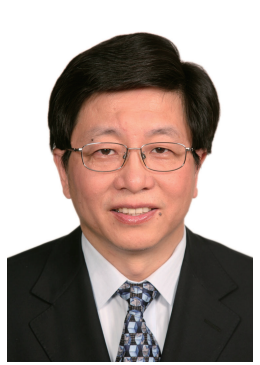

Weimin BAO was born in 1960. He received his Ph.D. degree in control theory and control engineering from Beihang University, Beijing. Currently, he is the director of the Science and Technology Commission of the China Aerospace Science and Technology Corporation. His research interests include artificial intelligence, automatic control, and flight vehicle design.

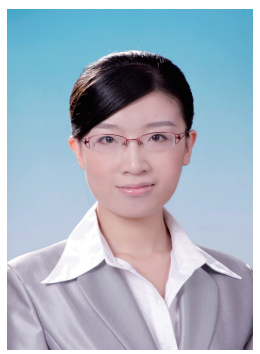

Yu ZHANG was born in 1987. She received her Master's degree in control theory and control engineering from Beihang University, Beijing, in 2011. Her research interests include artificial intelligence and automatic control.

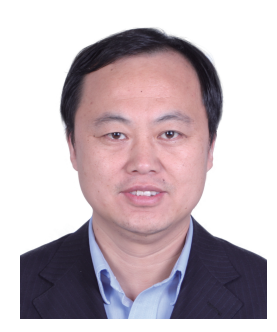

Zhenqiang QI was born in 1973. He received his $\mathrm{Ph} . \mathrm{D}$. degree in control theory and control engineering from Harbin Institute of Technology, Harbin, in 2004. Currently, he is a vice director of the Research and Development Department of the China Academy of Launch Vehicle Technology. His research interests include artificial intelligence, automatic control, and flight vehicle design. 